\title{
The Perceived Country Of Origin Images In Turkey
}

Mehmet Tigli, Marmara University, Turkey

Serdar Pirtini, Marmara University, Turkey

Y. Can Erdem, Yeditepe University, Turkey

\begin{abstract}
The purpose of this study is to investigate the effect of country-of-origin image in quality perceptions of Turkish consumers. Since the research already supports the fact that country-oforigin image reflects a consumer's general perception about the quality of products made in a particular country and the nature of people from that country, the authors aimed to search how consistent the Turkish consumers are in perceiving some products/product groups and the countries those products are associated with. The objective is to assess the matching of perceptions of some country images and the products. Both the product-country and the countryproduct match information can be used to assess consumers' purchase intentions by both marketing practitioners and the state authorities in managing country images. This study examined country-of-origin in terms of the fit between countries and product categories as perceived by a sample of 500 students/professionals in both major universities and numerous business institutions in Turkey. The findings indicated that the respondents were not consistent in associating the names of the products and the names of the countries with each other.
\end{abstract}

Keywords: Country of origin effect; country image; consumer behavior; marketing

\section{INTRODUCTION}

C)

he country of origin of a product is a basic extrinsic product cue, just like price, seller or brand name. It is an intangible product attribute and distinct from a physical product characteristic. The country-of-origin image of a product (COI), or product-country image (PCI), usually expressed through the phrase "made in" (Peterson \& Jolibert, 1995) and reflects a consumer's general perception about the quality of products made in a particular country and the nature of people from that country (Knight \& Calantone, 2000; Han, 1989). Some countries have a "good" reputation while others have a "poor" reputation for particular products. For instance, people are likely to evoke differing impressions of cars manufactured in Germany and Russia, TV sets made in Japan and Malaysia, or men's shoes made in Italy and Poland (Knight \& Calantone, 2000). Research shows that COI influences the evaluation of product classes, brands, and products in general. (Baughn \& Yaprak, 1993; Bilkey \& Nes, 1982; Knight \& Calantone, 2000). While a positive stereotype COI is used by marketers as a positive cue for almost all types of products, a negative stereotype may be a significant obstacle in both entering a new market or positioning in an existing one. Findings of the country-of-origin studies have consistently showed that consumers pervasively use country-of-origin information as an indicator of quality, and therefore, COI has been an integral part of the product evaluation process ( Kotler \& Gertner, 2002 ). It is also true that a given COI can be regarded as one dimension of the perceived quality for a certain product group, but it may not be relevant in other dimensions (for eg., Volvo's reputation for safety but its lower score for serviceability).

The structure of this paper is as follows. First, the COI concept is examined by reviewing the theoretical background and the hypotheses of the study are developed. After that, the paper presents a summary of the methodology used to collect and analyze the data. Finally, main findings and implications are discussed. 


\section{THEORETICAL BACKGROUND}

\section{Country-of-origin research in International Marketing}

The potential impact of country of origin on buyer perceptions and evaluations has always been one of the most widely researched aspects of consumer behavior phenomena in the international business, marketing and consumer behavior literature (Tan \& Farley, 1987; Peterson \& Jolibert, 1995). Since the publication of the first article of Schooler's "Product Bias in the Central American Common Market" in 1965, more than 300 articles have been published on COI with a great deal of diversity in countries as origins, product categories and consumers surveyed (Usunier \& Lee, 2005). Early research on COI has documented statistically significant COI effects across countries, for various product categories for both industrial buyers and personal consumers. In 1982, Bilkey and Nes qualitatively evaluated the results of $25 \mathrm{COO}$ studies and concluded that "all of the studies reviewed indicate that country of origin does indeed influence buyers' perceptions of the products involved" (p.90). Since the basic objective of the early research was to demonstrate that the COI cue actually influenced consumers' evaluations of products, attempting the direction/reason of the COI effects was only a secondary objective. These made the effects seem stronger than they would be under more realistic circumstances (Bilkey \& Nes, 1982). During the 80s and the 90s, the research was more focused on the effects of $\mathrm{COI}$ in relation to other extrinsic and intrinsic product attributes such as price (Usunier \& Cestre, 2007; Usunier \& Lee, 2005; Bilkey \& Nes, 1982; Papadopoulos \& Heslop, 2002). In 1994, Peterson and Jolibert identified 184 papers published in academic journals dealing with country image effects. During the late 90s and the early 2000s, the published reviews showed that the effect of COI was less when COI information is included along with other cues like product and price (Verlegh \& Steenkamp, 1999) and that the average effect of COI on perception of quality and reliability dropped significantly when multiple attributes were added to the COI information. Peterson and Jolibert (1995) and Verlegh and Sttenkamp (1999) also showed that the effect of COI was stronger in perception of the brand quality than attitude toward the product or purchase intention. Another major finding was that COI effect was used as a reliable cue of brand quality more than to infer quality due to the origin country. Agrawal and Kamakura (1999) found that the countries were perceived differently in the objective quality of the consumer electronics and COI had no significant impact on the charged prices. Additionally, Verlegh and Steenkamp (1999) suggested that COI information was used as a cue conveying symbolic and emotional value and as a right to do things (Askegaard \& Ger, 1998; Klein, 1998). Several other scholars have attempted to understand the use of COI effect in the context of information processing and knowledge activation. One major finding was that $\mathrm{COI}$ effect could serve as a stereotype measure for other product features for the consumers who are unfamiliar with the product (Han, 1989).

Tse and Gorn (1993) found that the country-of-origin had a significant impact in consumer product evaluation of stereo sound systems. Elliot and Cameron (1994) also investigated the effect of country-of-origin across different product categories and their findings showed that country of origin was considered significantly less important than product quality and price by the respondents.

Akaah and Yaprak (1993) also examined images of three countries (Ghana, Turkey and US) on product evaluations of 225 graduate students and found that the country of origin was not significantly effective in their decision making process.

Canli and Maheswaran (2000) studied the psychological processes underlying COI evaluations and found that both motivational intensity and motivational direction of the respondents were important in moderating the effect of information type on COI evaluations.

Balabanis and Diamantopoulos (2008) investigated the abilities of consumers in identifying the correct country of origin and the factors affecting their identification with the implications of identification process on brand evaluation. The findings indicated the limited ability of consumers to classify brands correctly according to their origin with major differences in the classification of different brands to their country of origin. Furthermore, consumer ethnocentrism and socio demographics of respondents seemed to have an important role in identification. Another important finding was that COI was not observed to have a significant impact on brand evaluations of all the product groups included in the research (Balabanis \& Diamantopoulos, 2008). 
In conclusion, extensive research has supported the impact of country of origin on both positive and negative attitudes toward foreign products/services which made COI an important asset in the arena of international marketing for many years (Kotler \& Gertner, 2002). However, COI is no longer a major issue for international marketing due to the developments mainly leading to a global marketplace: multinational production, global branding, international marketing operations, and the decline of origin labeling in World Trade Organization (Usunier, 2006).

Some products are typically associated with a country of origin (for eg. cigars with Cuba) and others are associated with several countries (for eg. tourism is associated with many countries like Egypt, Italy, and France). Yet, many products are not associated with any country. This matching is also true for the countries. Some countries are associated with certain products because of various reasons. Those countries may be considered either as the place of invention of the product or the common place of use. Some historical and/or cultural reasons may lead to this association. Assessment of such a perceived association by the consumers of any country may be very relevant in the global environment where consumers are free to purchase any product of different origins. The purpose of this particular study is to assess this country-product association made by the Turkish consumers by focusing on categorization outcomes but not on outcomes.

\section{THE RESEARCH}

The list of thirty-five countries used in this study has been organized from the list of developed and developing countries of International Monetary Fund (IMF). A total of thirty-nine products/product groups have been identified through two different focus group studies. The questionnaire used in the research was composed of three sections. The first part included the name list of the thirty-five countries and the list of five products that had been associated with that country in a pilot study across the name of each county. The respondents were asked to rank the product alternatives in the order of association $(1=$ the most associated and $5=$ the least associated). The second part included the name list of the products/sectors and five different alternative country names that were the most associated countries with that product in the pilot study. The task of the respondents was again to mark the country names in the order of the assumed association. In the third part, demographics of the respondents were asked.

Since the objective of the research was to assess both the statistical significance and strength of the association, it has been hypothesized that there was no association between the variables (names of the countries and the products) when the respondents were asked to match them in two stages.

$\mathbf{H}_{\mathbf{0}}$ : Turkish consumers are not consistent in their decisions to match countries with products and products with countries.

H1: Turkish consumers are consistent in their decisions to match countries with products and products with countries.

\section{DATA ANALYSIS AND EMPIRICAL FINDINGS}

The replies of the respondents were analyzed with SPSS and the null hypothesis of " $\mathrm{H}_{0}$ : The respondents are not consistent in matching goods/services with countries and countries with products/services" has been tested. Paired t-test was used to determine whether a systematic association existed between two variables of countryproduct-country matches of respondents. It was observed that for only eight of the fifty-six pairs, the respondents associated products and countries. Therefore it can be claimed that the Turkish consumers are consistent in matching products and countries for only six pairs of both variables which are: Gold-South Africa, Beer-Mexico, Cell phoneFinland, Education-Switzerland, Cinema-India, Olive oil-Spain, Wine-Spain, and Wine-Portugal. The pairedsamples test statistics are listed in Table.1.

The major finding of this research is that Turkish customers seem not to be consistent in associating the product names with the country names and the country names with the product names for sets of product/country 
names. This finding shows that knowledge of the customers about the origins of some products and the popular products from some countries is not significantly relevant. This may be due to the fact that those countries have not created unique images among Turkish consumers matching with those products or it may be because of the lack of knowledge or interest of consumers. Another indicator of this lack of unique images is the fact that wine is associated both Spain and Portugal but not with France as expected. This shows that marketers of thirty-one products do not enjoy the privilege of being associated with certain countries directly by the Turkish consumers. Apparently what people remember when they hear the names of the countries are not those product groupings.

\section{MANAGERIAL IMPLICATIONS}

The image of a country, the way it is formed and the changes of this image in time should be of a great concern to government, industry and individual firms especially for the ones doing foreign trade. The findings of COI research can be very productive for both the state institutions that are trying to establish country images abroad like tourism executives and investment departments and the entrepreneurs who are having investments in foreign countries and planning joint ventures in home country. Managing the image of a country may not only influence the foreign trade balances but also have an impact on the long term commercialization of certain products and services like cultural and sporting products. The authors believe that proper management of a nation's image may provide the business institutions with a competitive advantage in world markets but the authorities both in public and private sector seem not to take these effects into consideration as much as they should. In the process of export/import planning, the stereotypes/beliefs of consumers in different countries may be very informative in both short and long term plans. Of course, knowledge about the perception of some foreign brands matched with particular consumers in different countries would be much more useful in planning especially imports. Individual exporters who want to benefit from favorable country image should highlight products of higher quality from the same country in the international market. This emphasis may help consumers to generalize product information over many of the products of the country. Alternatively, marketers may need to disassociate their products from non-reputable products of the same country.

The global companies with various manufacturing and procurement facilities in different geographical regions/countries may also take the advantage of introducing new products made in a favorable country of origin.

In this particular study, Turkish consumers were asked to match both different products with various countries and the countries with products in a two-stage process. The major implications of the conclusion are that the respondents seemed not to be consistent in two consecutive stages of matching. In other words, what product was selected as a match of a certain country was not associated with that particular country when the name of the country was the stimulus. This does not show that COI is not relevant in Turkey but it may mean that Turkish consumers do not have a direct association between product names and the origin countries for the thirty-one product groups searched in this study. This may be valuable information for the major exporters of those products regarding the Turkish market.

\section{LIMITATIONS OF THE STUDY AND FUTURE RESEARCH AVENUES}

The major limitation of this study is the way questionnaires were administrated to the respondents; that is, through the website. The questionnaire has been placed on the website of a major university in Istanbul and the respondents from various institutions were encouraged to fill it out. Because of the prestigious names of the universities and thanks to the efforts of the researchers, the response rate was relatively high, but already known drawbacks of using the Internet were relevant. Controlling who was in the sample was not possible and the dynamics of more personal approaches, like face-to-face interviews, were lacking. The data collection method in this research is based on only one stimulus; namely, either product or country name, given to the respondents assuming that they were familiar with either or both of the names. In cases where the respondents are not familiar with the stimulus, they did not tick a box. This led to a more accurate picture of linkages between products and countries with more missing replies. 
Table.1: Paired Samples Test Statistics

\begin{tabular}{|c|c|c|c|c|c|c|c|}
\hline \multicolumn{8}{|c|}{ Paired Samples T - Test } \\
\hline \multicolumn{2}{|c|}{$\begin{array}{c}\text { Product Country - } \\
\text { Country Product paires }\end{array}$} & $\begin{array}{c}\text { Paired Differences } \\
\text { Mean }\end{array}$ & $\begin{array}{c}\text { Std. } \\
\text { Deviation }\end{array}$ & $\begin{array}{c}\text { Sig. } \\
(2 \text { tailed })\end{array}$ & $\mathbf{H}_{\mathbf{0}}$ & Result & Correlation \\
\hline Pair 1 & Gold - South Africa & $-0,063$ & 1,172 & 0,258 & Accept & Not different & 0,606 \\
\hline Pair 2 & Shoe Industry - Italy & $-1,052$ & 1,455 & 0,000 & Reject & Different & 0,429 \\
\hline Pair 3 & Fishing - Norway & $-0,234$ & 0,931 & 0,000 & Reject & Different & 0,681 \\
\hline Pair 4 & \begin{tabular}{|l|} 
Fishing - Japan \\
\end{tabular} & $-0,820$ & 1,524 & 0,000 & Reject & Different & 0,483 \\
\hline Pair 5 & Fishing - Sweden & 0,273 & 1,562 & 0,000 & Reject & Different & 0,336 \\
\hline Pair 6 & Banking - Switzerland & $-0,369$ & 1,161 & 0,000 & Reject & Different & 0,571 \\
\hline Pair 7 & White goods - Germany & $-0,895$ & 1,310 & 0,000 & Reject & Different & 0,407 \\
\hline Pair 8 & \begin{tabular}{|l|} 
I.T. - India \\
\end{tabular} & 0,257 & 1,249 & 0,000 & Reject & Different & 0,722 \\
\hline Pair 9 & I.T.- Japan & $-0,168$ & 1,154 & 0,003 & Reject & Different & 0,562 \\
\hline Pair 10 & I.T. - USA & $-0,669$ & 1,314 & 0,000 & Reject & Different & 0,549 \\
\hline Pair 11 & Beer - Germany & $-0,306$ & 1,154 & 0,000 & Reject & Different & 0,604 \\
\hline Pair 12 & Beer - Argentina & $-0,633$ & 1,430 & 0,000 & Reject & Different & 0,445 \\
\hline Pair 13 & Beer-Mexico & $-0,039$ & 1,381 & 0,570 & Accept & Not different & 0,496 \\
\hline Pair 14 & Cell phone - Finland & $-0,043$ & 1,060 & 0,396 & Accept & Not different & 0,769 \\
\hline Pair 15 & Cell phone - Sweden & 0,220 & 1,442 & 0,002 & Reject & Different & 0,491 \\
\hline Pair 16 & Tea - U.K. & $-0,341$ & 1,283 & 0,000 & Reject & Different & 0,607 \\
\hline Pair 17 & \begin{tabular}{|l|} 
Chocolate - Switzerland \\
\end{tabular} & $-0,573$ & 1,316 & 0,000 & Accept & Different & 0,546 \\
\hline Pair 18 & \begin{tabular}{|l|} 
Chocolate - Belgium \\
\end{tabular} & 0,321 & 1,412 & 0,000 & Accept & Different & 0,447 \\
\hline Pair 19 & Education - U.K. & $-0,140$ & 1,110 & 0,009 & Reject & Different & 0,601 \\
\hline Pair 20 & \begin{tabular}{|l} 
Education - Canada \\
\end{tabular} & 0,140 & 1,259 & 0,021 & Reject & Different & 0,542 \\
\hline Pair 21 & \begin{tabular}{|l|} 
Education - Switzerland \\
\end{tabular} & $-0,071$ & 1,387 & 0,292 & Accept & Not different & 0,528 \\
\hline Pair 22 & Football - Brazil & $-0,088$ & 0,705 & 0,008 & Reject & Different & 0,808 \\
\hline Pair 23 & Football-U.K. & 0,340 & 1,062 & 0,000 & Reject & Different & 0,617 \\
\hline Pair 24 & Football - Argentina & 0,515 & 1,095 & 0,000 & Reject & Different & 0,544 \\
\hline Pair 25 & Coffee - Brazil & $-0,539$ & 1,347 & 0,000 & Reject & Different & 0,492 \\
\hline Pair 26 & Ready wear - Italy & $-0,670$ & 1,375 & 0,000 & Reject & Different & 0,458 \\
\hline Pair 27 & Ready wear - France & $-0,218$ & 1,432 & 0,002 & Reject & Different & 0,476 \\
\hline Pair 28 & Ready wear - Spain & $-0,198$ & 1,315 & 0,002 & Reject & Different & 0,529 \\
\hline Pair 29 & Pasta - Italy & $-0,190$ & 0,683 & 0,000 & Reject & Different & 0,828 \\
\hline Pair 30 & Furniture - Sweden & $-0,447$ & 1,526 & 0,000 & Reject & Different & 0,445 \\
\hline Pair 31 & $\begin{array}{l}\text { Automotive industry - } \\
\text { Germany }\end{array}$ & $-0,121$ & 0,811 & 0,002 & Reject & Different & 0,764 \\
\hline Pair 32 & Automobile - Japan & $-0,723$ & 1,365 & 0,000 & Reject & Different & 0,458 \\
\hline Pair 33 & Automobile - Sweden & 0,567 & 1,434 & 0,000 & Reject & Different & 0,396 \\
\hline Pair 34 & Toys - China & $-0,564$ & 1,177 & 0,000 & Reject & Different & 0,570 \\
\hline Pair 35 & Perfume - France & $-0,414$ & 0,914 & 0,000 & Reject & Different & 0,709 \\
\hline Pair 36 & Cheese - Holland & $-0,636$ & 1,452 & 0,000 & Reject & Different & 0,485 \\
\hline Pair 37 & Cheese - France & $-0,757$ & 1,430 & 0,000 & Reject & Different & 0,509 \\
\hline Pair 38 & Cheese - Denmark & 0,666 & 1,734 & 0,000 & Reject & Different & 0,316 \\
\hline Pair 39 & Watch - Switzerland & $-0,308$ & 1,230 & 0,000 & Reject & Different & 0,582 \\
\hline Pair 40 & Ceramic - China & $-0,839$ & 1,672 & 0,000 & Reject & Different & 0,370 \\
\hline Pair 41 & Cinema - USA & $-0,583$ & 1,052 & 0,000 & Reject & Different & 0,646 \\
\hline Pair 42 & Cinema - India & 0,038 & 1,215 & 0,520 & Accept & Not different & 0,607 \\
\hline Pair 43 & Grains - Turkey & $-0,998$ & 1,536 & 0,000 & Reject & Different & 0,283 \\
\hline Pair 44 & Grains - Russia & $-0,338$ & 1,301 & 0,000 & Reject & Different & 0,478 \\
\hline Pair 45 & Grains - Egypt & $-0,836$ & 1,506 & 0,000 & Reject & Different & 0,386 \\
\hline Pair 46 & Tourism - Spain & 0,483 & 1,269 & 0,000 & Reject & Different & 0,508 \\
\hline Pair 47 & Tourism - Turkey & 0,383 & 1,210 & 0,000 & Reject & Different & 0,571 \\
\hline Pair 48 & Tourism - Greece & 0,585 & 1,284 & 0,000 & Reject & Different & 0,497 \\
\hline Pair 49 & Tourism - Egypt & 0,719 & 1,402 & 0,000 & Reject & Different & 0,469 \\
\hline Pair 50 & Tobacco - Cuba & $-0,556$ & 0,988 & 0,000 & Reject & Different & 0,600 \\
\hline Pair 51 & Olive oil - Turkey & $-0,886$ & 1,423 & 0,000 & Reject & Different & 0,430 \\
\hline Pair 52 & Olive oil - Greece & $-0,277$ & 1,334 & 0,000 & Reject & Different & 0,437 \\
\hline Pair 53 & Olive oil - Spain & 0,127 & 1,417 & 0,070 & Accept & Not different & 0,395 \\
\hline Pair 54 & Wine - France & $-0,288$ & 1,061 & 0,000 & Reject & Different & 0,623 \\
\hline Pair 55 & Wine - Portugal & $-0,120$ & 1,476 & 0,102 & Accept & Not different & 0,404 \\
\hline Pair 56 & Wine - Spain & 0,069 & 1,384 & 0,316 & Accept & Not different & 0,360 \\
\hline
\end{tabular}


It is already known that attitudes toward a product or a country depend on personality, personal experience, and exposed information about that product/country, culture, values, motives and capacities. In this study, the above factors have not been covered. Besides, the choices of the respondents depended on the stereotypes, first impressions, feelings, ideas, emotions and connotations associated with that country and the product.

The authors of this manuscript are planning to conduct similar surveys in various countries with developed and developing economies and representing individualist and collectivist cultures around the world. When the respondents are asked to match the products with countries or countries with products, they can also be asked to comment on the design, brand and other intrinsic and extrinsic factors in shaping up the association. In order to determine the strength of the product-country association, some other contributing factors that can be investigated are product familiarity, product involvement, and country familiarity. Investigation of these factors, along with the construct of "willingness to purchase", would result in a conceptualization of a more comprehensive study to better understand the impact of country-of-origin effect.

\section{AUTHOR INFORMATION}

Assoc. Prof. Mehmet Tigli received his B.A. (1991), M.B.A. (1993) and Ph.D. (1998) Degrees from Marmara University where he is an associate professor of marketing.

Assoc. Prof. Serdar Pirtini received his B.A. from Anadolu University (1991), M.A. (1993) and Ph.D. (1998) from Marmara University where he is an associate professor of marketing.

Assist. Prof. Y.Can Erdem received his B.A. from Middle East Technical University (1978), his M.B.A. from East Carolina University, North Carolina (1981) and his Ph.D. from Yeditepe University of Istanbul (2006) where he is currently an assistant professor of marketing.

\section{REFERENCES}

1. Akaah, Ishmael P., Yaprak, Attila. (1993). Assessing the influence of country of origin on product evaluations: An application of conjoint methodology. Journal of International Consumer Marketing, 5(2), 39.

2. Agrawal, J., \& W. Kamakura, Country of Origin: a competitive advantage? International Journal of Research in Marketing, 16(4), pp.255-267, 1999.

3. Askegaard, S., \& G.Ger, Product-Country Images: Towards a Contextualized Approach. European Advances in Consumer Research, III, pp. 50-58, 1998.

4. Balabanis, G. \& A. Diamantopolos, Domestic Country Bias, Country-of-origin Effects, and Consumer Ethnocentrism: A Multidimensional Unfolding Approach, Journal of Academy of Marketing Science, 32(1), pp. 80-93, 2004.

5. Balabanis, G. \& A.Diamantopoulos, Brand Origin Identification by Consumers: A Classification Perspective, Journal of International Marketing, 16(1), 39, 2008.

6. Balabanis, G., R. Mueller, R., \& T.C. Melewar, The Human values' lenses of country of origin images. International Marketing Review, 19(6), pp.582, 2002.

7. Baugh, C.C. \& A. Yaprak, Mapping Country-of-origin Research: Recent Developments and Emerging Avenues in Product Country Images: Impact and Role in International Marketing, Nicholas Papadopoulos and Louise Heslop, New York: International Business Press, pp.89-115, 1993.

8. Bilkey, W.J. \& E. Nes, Country-of-origin effects on product evaluations, Journal of International Business Studies, 13(1), pp. 89-99, 1982.

9. Canli, Z.G. \&D. Maheswaran,, Determinants of Country-of-origin evaluations, Journal of Consumer Research, 27(1), pp. 96-109, 2000.

10. Elliot, G. R. \& R.C. Cameron,, Consumer perception of product quality and the country-of-origin effect, Journal of International Marketing 2 2(2), pp. 49, 1994.

11. Han, C.M., Country Image: Halo or Summary Construct? Journal of Marketing Research, 26 (2), pp. 222$229,1989$. 
12. Klein, G., R .Ettenson \& M.D.Morris, The animosity model of foreign product purchase: An empirical test in the People's Republic of China, Journal of Marketing, 62, (1), pp.89-100, 1998.

13. Knight, G.A. \& R.J. Calantone, A flexible model of consumer county-of-origin perceptions: A crosscultural investigation, International Marketing Review, 17 (2), pp.127-137, 2000.

14. Kotler, P., \& D. Gertner, Country as a brand, product, and beyond: A place marketing and brand management perspective, The Journal of Brand Management, 9(4/5), pp.249-258, 2002.

15. Papadopoulos, N, \& L. Heslop, Country equity and country branding: Problems and prospects, Journal of Brand Management, 9 (4/5), pp.294-307, 2002.

16. Peterson, R.A. \& A.J.P. Jolibert, A meta-analysis of country-of-origin effects, Journal of International Business Studies, 26(4), p. 883, 1995.

17. Schooler, R. D., Product bias in the Central American common market, Journal of Marketing Research, 11, November, pp.394-397, 1965.

18. Tan, Chin T. \& John U. Farley, The Impact of Cultural Patterns on Cognition and Intention in Singapore, Journal of Consumer Research, 13, pp.540-544, 1987.

19. Tse, D.K., G.J. Gorn, An experiment on the salience of country-origin in the era of global brands, Journal of International Marketing, 1(1), pp.57-77, 1993.

20. Usunier, J.C., \& J.A. Lee, Marketing Across Cultures. Prentice Hall, Harlow: England, 2005.

21. Usunier, J.C., \& G. Cestre, Product Ethnicity: Revisiting the Match between Products and Countries, Journal of International Marketing, 15(3), pp.32-72, 2007.

22. Usunier, J.C., Relevance in business research: the case of country-of-origin research in marketing, European Marketing Review, 3, pp.60-73, 2006.

23. Verlegh, P.W.J. \& J.B. Steenkamp, A review and meta-analysis of country-of-origin research, Journal of Economic Psychology, 20, pp.521-546, 1999. 
NOTES 